\title{
LA IX DUQUESA DE OSUNA Y EL JARDÍN DE EL CAPRICHO (MADRID): LA RECEPCIÓN DE LA ANTIGÜEDAD CLÁSICA EN EL PROGRAMA ICONOGRÁFICO
}

\author{
The $9^{\text {th }}$ Duchess of Osuna and the Garden of "El Capricho" \\ (Madrid): the Reception of the Classical Antiquity \\ in the Iconographic Scheme
}

\author{
Noelia CASES MORA \\ Universidad de Alicante \\ noelia.cases@ua.com
}

Fecha de recepción: 15/10/2018

Fecha de aceptación definitiva: 10/04/2019

RESUMEN: En este artículo se analiza la recepción de los temas clásicos en el programa iconográfico del jardín madrileño de El Capricho. El carácter de la recepción de la Antigüedad en este espacio reside en las inquietudes ilustradas de la IX duquesa de Osuna y encaja, a su vez, dentro de las corrientes paisajísticas en materia de jardines que se estaban desarrollando en Europa durante el siglo XVIII.

Palabras clave: jardín paisajista; clasicismo; programa iconográfico; Ilustración española; Alameda de Osuna; El Capricho.

ABSTRACT: In this paper we analyze the reception of the Classical world in the iconographic scheme of the garden of "El Capricho". The charasteristic of the reception of Antiquity in this place is due to the personality of the $9^{\text {th }}$ Duchess of Osuna. Moreover, it is being recognized that the carácter of this garden fits in the European cultural trends of the $18^{\text {th }}$ century.

Key words: paisajistic garden; classicism; iconographic scheme; Spanish Illustration; Alameda de Osuna; El Capricho. 


\section{INTRODUCCIÓN}

El jardín y el palacio de El Capricho constituyeron una villa suburbana ${ }^{1}$ emplazada en la Alameda de Osuna (Madrid), como resultado de la iniciativa de la IX duquesa de Osuna, María Josefa de Pimentel, quien impulsó su creación entre finales del siglo XVIII y comienzos del XIX. Desde su compra por el Ayuntamiento de Madrid en el año 1973, se han realizado varias intervenciones de restauración y puesta en valor, haciendo de él uno de los jardines históricos visitables más destacados de la ciudad. La posición social destacada de los duques dentro del entorno de la Corte Real y la apertura intelectual de la IX duquesa de Osuna a las influencias inglesas y francesas del momento hacen de este espacio uno de los sitios más singulares de Madrid. En él encontramos un programa iconográfico que utiliza temas clásicos y, dada la particularidad de la arquitectura de este jardín, perseguimos como objetivo realizar un análisis histórico del contexto en que se concibió este programa iconográfico, pudiendo entender la recepción de la Antigüedad clásica en El Capricho como parte intrínseca de las inquietudes intelectuales de la duquesa de Osuna y de las corrientes paisajísticas del momento. La construcción de este espacio pretendía crear un lugar de esparcimiento familiar, pero también de reuniones sociales, así como un punto de encuentro para los intelectuales más destacados del momento.

Centraremos nuestro estudio en el periodo en que la duquesa dirigió la construcción del jardín, dejando al margen las reformas posteriores llevadas a cabo por sus herederos, puesto que consideramos que la originalidad de este espacio se relaciona directamente con la personalidad de la IX duquesa de Osuna, integrada en la corriente ilustrada que débilmente se abría paso en España en la segunda mitad del siglo XVIII. El análisis de la recepción de la Antigüedad en épocas posteriores se ha convertido en una línea de investigación fructífera que ha aportado numerosas novedades sobre la utilización de los temas clásicos con diferentes propósitos, como puede ser la legitimación del gobernante. Este tipo de estudio no ha sido aplicado al jardín histórico de El Capricho, por lo que esperamos realizar una contribución valiosa con este trabajo.

En este sentido, la metodología consiste en el estudio de la situación de España a finales del siglo XVIII, con el objetivo de poder situar el proyecto en su contexto histórico, así como analizar qué tipo de jardines y programas iconográficos se estaban desarrollando en el resto de países europeos desde el Renacimiento y cómo utilizaban los temas clásicos. Posteriormente, analizaremos los elementos arquitectónicos y decorativos más significativos del jardín de la Alameda de Osuna para analizar cómo incorpora los motivos de la Antigüedad clásica. Finalmente,

1. La existencia de villas suburbanas o de recreo fue una constante en el Madrid dieciochesco. De hecho, el ducado de Osuna poseyó otra villa de este tipo en la Quinta del Aguilar, aunque por menor espacio temporal. Véase: LASSO DE la VEGA ZAMORA, M. Quintas de recreo. Las casas de campo de la aristocracia alrededor de Madrid. Madrid: Ayuntamiento de Madrid, pp. 117-122. 
pretendemos realizar una valoración acerca de cómo encaja todo ello con lo que se estaba desarrollando en Europa al mismo tiempo.

\section{CONTEXTO HistóRICO: EL DUCADO DE OSUNA Y LA ILUSTRACIÓN ESPAÑOLA}

María Josefa de Pimentel (1752-1834), entre otros títulos, fue la condesaduquesa de Benavente y quedó como única heredera de todos los títulos y propiedades de su familia, los Benavente, una de las más ilustres de España en la época ${ }^{2}$. Contrajo matrimonio con Pedro Alcántara Telléz Girón, duque de Osuna, otra de las casas aristocráticas españolas más poderosas, quien heredaría también todos los títulos de su familia al morir el primogénito de los Osuna³. La unión de dos familias tan destacadas de la aristocracia española del siglo XVIII nos permite comprender el importante papel que desempeñaron dentro del ambiente cortesano. En el periodo que nos interesa estudiar, a finales del siglo XVIII, comenzó el reinado de Carlos IV (1788-1808)

Frente a la reina María Luisa de Parma o la duquesa de Alba, que encarnaban un papel vinculado con el tópico de la mujer en la sociedad del siglo XVIII, la duquesa de Osuna representó un arquetipo de mujer culta de espíritu abierto e inquieto. Las tres mujeres fueron los modelos en que se fijaba la corte madrileña a finales del siglo XVIII, produciéndose una rivalidad entre ellas que se plasmaba en sus "salones", palacios, jardines y obras de arte 5 . Sin embargo, la duquesa de Osuna destacó en la sociedad y en los círculos intelectuales por sus inquietudes, relacionadas con las corrientes ilustradas que se estaban desarrollando en Europa, así como su mayor refinamiento cultural ${ }^{6}$. La Alameda fue, junto al palacete de la Moncloa de la duquesa de Alba, uno de los dos centros campestres de divertimento de la alta sociedad de Madrid en el siglo XVIII

2. Sobre la vida y personalidad de la IX duquesa de Osuna véase: FERNÁndeZ-QuinTANILLA, Paloma. La IX Duquesa de Osuna, una ilustrada en la Corte de Carlos III. Aranjuez: Ediciones Doce Calles, 2017.

3. Atienza Hernández, Ignacio. Aristocracia, Poder y Riqueza en la España Moderna. La Casa de Osuna: siglos XV-XIX. Madrid: Editorial Siglo XXI, 1987, p. 107.

4. Sobre el ascenso al trono de Carlos IV, su relación con la familia Osuna y la celebración de fiestas privadas en el ámbito cortesano, véase el siguiente artículo: MARTínez MEDiNA, África. "La vivienda aristocrática, escenario de la fiesta: festejos realizados por los Condes-Duques de Benavente con motivo de la exaltación al trono de Carlos IV, 19 de enero de 1789". En Romero Ferrer, Alberto (coord.). De la Ilustración al romanticismo 1750-1850: VI encuentro "Juego, fiesta y transgresión" (Cádiz 16, 17 y 18 de octubre de 1991). Editorial Árbol académico, 1995, pp. 309-317.

5. ARIZA MuÑoz, Carmen. Los jardines de Madrid en el siglo XIX. Madrid: Editorial Avapiés, 1988, p. 45 .

6. Bolufer Peruga, Mónica. Mujeres e Ilustración. La construcción de la feminidad en la España del siglo XVIII. Valencia: Institución Alfonso el Magnánimo, 1998, p. 342.

7. Atienza Hernández, Ignacio. Aristocracia, Poder y Riqueza en la España Moderna. La Casa de Osuna: siglos XV-XIX. Madrid: Editorial Siglo XXI, 1987, p. 108. 
De este modo, la casa de los Osuna de la Puerta de la Vega, y después El Capricho, se convirtió en uno de los lugares preferidos por la minoría ilustrada española de finales del siglo XVIII, inmersa en iniciativas e instituciones de refor$\mathrm{ma}^{8}$. La propia duquesa era, desde 1786, la presidenta de la Sección Femenina de la Sociedad Económica de Madrid ${ }^{9}$, por lo que algunos autores han considerado que el proyecto que desarrolló en la Alameda de Osuna puede definirse como una verdadera "experiencia fisiocrática ${ }^{10}$. Desde su posición, intentó poner en práctica sus ideales impulsando una reforma agraria, ganadera, sanitaria y de instrucción pública $^{11}$. Por todo ello, debemos contextualizar el jardín de la duquesa de Osuna en el ambiente ilustrado en el que se movió, aunque en el caso de España fue un movimiento minoritario y desarrollado de forma más tardía que en otros países europeos como Inglaterra o Francia, con los que la duquesa mantenía vínculos culturales para acceder a las novedades ${ }^{12}$.

La minoría ilustrada española emprendió desde mediados del siglo XVIII una tarea de renovación física y moral del país a través de nuevas instituciones como las Sociedades Económicas de Amigos del País, buscando revitalizar el comercio, crear nuevas industrias y una reforma agraria que hiciera de la explotación agraria y ganadera una actividad fructífera ${ }^{13}$. En este contexto tiene sentido "El Capricho», puesto que la duquesa estuvo implicada en estas instituciones y fue impulsora de las nuevas ideas. Por su parte, el duque de Osuna, Pedro Alcántara, también destacó por su firme compromiso reformista con la Ilustración ${ }^{14}$. Al igual que la duquesa, el duque de Osuna también tuvo amplias inquietudes intelectuales, formando

8. El ducado de Osuna poseía tres palacios en Madrid: en Leganitos, Puerta de la Vega y las Vistillas, además de dos villas suburbanas, la de la Alameda de Osuna y, por un tiempo, otra en la Quinta del Aguilar. Sobre la disposición y significación de estas propiedades, véase: NAVASCUÉS Palacio, Pedro. "Casas-palacio de la familia Osuna». En Jardines clásicos madrileños. Madrid: Museo Municipal, 1981, pp. 125-133; PÉREZ HernÁndeZ, Isabel. "Los palacios urbanos y las villas suburbanas de la casa nobiliaria de Osuna en la conformación de las periferias oeste y este de Madrid». En ALBERTO Alves, Luis y García García, Francisco (coords.). V Congresso Internacional Cidades Criativas: Libro de Actas, vol. 1, 2017, pp. 28-31.

9. Crespo Delgado, Daniel. Árboles para una capital. Árboles en el Madrid de la Ilustración. Aranjuez: Ediciones Doce Calles, 2012, p. 115.

10. NAvascués Palacio, Pedro. "La Alameda de Osuna: una villa suburbana». Revista Estudios Pro-Arte, 1975 , n. ${ }^{\circ}$ 2, p. 8.

11. Desde su participación en la Sociedad Económica Matritense, a partir de la creación de una sección femenina de la cual fue presidenta, impulsó la promoción de la mejora de los cultivos y su productividad en el ámbito madrileño, financiando incluso premios. Sobre esta cuestión, véase CRESPO Delgado, Daniel. Árboles para una capital. Árboles en el Madrid de la Ilustración. Aranjuez: Ediciones Doce Calles, 2012.

12. De dichas relaciones queda evidencia en su correspondencia: MuÑOZ RoCA-TALLADA, Carme. La condesa-duquesa de Benavente: una vida en unas cartas. Madrid: Espasa-Calpe, 1955.

13. Crespo Delgado, Daniel. Árboles para una capital. Árboles en el Madrid de la Ilustración. Aranjuez: Ediciones Doce Calles, 2012, p. 115.

14. FernándeZ-Quintanilla, Paloma. La IX Duquesa de Osuna, una ilustrada en la Corte de Carlos III. Aranjuez: Ediciones Doce Calles, 2017, p. 74. 
parte de la Real Academia de la Lengua y la Academia de San Fernando, así como presidente de la Real Sociedad Económica Matritense de Amigos del País ${ }^{15}$.

Sin embargo, también es importante considerar su inserción en un ámbito cultural más amplio, puesto que consideramos que la recepción de elementos de la Antigüedad clásica en el programa iconográfico de El Capricho tiene gran relación con la figura de la duquesa de Osuna dentro de la cultura europea de finales del XVIII y comienzos del XIX. Los duques habían estado en Francia como embajadores de la Corona española y, durante una de sus estancias en París ${ }^{16}$, la duquesa de Osuna conoció a Pougens, amigo de D'Alembert, con quien mantuvo una intensa correspondencia para que este la mantuviera al tanto de las últimas novedades en la capital francesa, como el Journal des Modes, té, telas, y sobre todo le enviara los libros más recientes ${ }^{17}$.

Por esta razón, debemos vincular la personalidad de la duquesa y sus inquietudes intelectuales con la cultura francesa contemporánea. La duquesa poseía una amplia biblioteca con secciones dedicadas a la filosofía, la política, la Historia Antigua o las antigüedades, entre otras ${ }^{18}$. La mayoría de los autores recogidos en esta biblioteca eran franceses o ingleses traducidos al francés, así como enciclopedistas y autores prohibidos en España por la Inquisición. Además de Pougens, la duquesa tuvo otros "corresponsales» y puntos de contacto con el medio francés, puesto que deseaba estar al día con respecto a las novedades que se publicaban fuera de España. La biblioteca de los Osuna era una de las mejores de España ${ }^{19}$, e incluso abrieron una biblioteca pública en la calle Leganitos de Madrid, que perduró hasta 1808.

Por otro lado, cabe destacar dentro del trazado de este breve contexto que la duquesa de Osuna fue una gran amante de la pintura, llegando a formar una colección con obras de Rubens, Rafael, Van Dyck, pero sobre todo es necesario mencionar su relación con Goya. En el palacio de la Alameda, además de una impresionante biblioteca, tenía una magnifica pinacoteca ${ }^{20}$. La duquesa conoció a

15. Crespo Delgado, Daniel. Árboles para una capital. Árboles en el Madrid de la Ilustración. Aranjuez: Ediciones Doce Calles, 2012, pp. 90-91.

16. TOVAR MARTín, Virginia. Relaciones artísticas entre Madrid y París en el siglo XVIII. Madrid: Artes Gráficas Municipales, 1990.

17. Luengo AÑón, Mónica. "El Capricho de la Alameda de Osuna». En AÑón Feliú, Carmen y Luengo AÑón, Mónica (coords.). Jardín y romanticismo. Madrid: Comunidad de Madrid, 2004, p. 75.

18. Navascués Palacio, Pedro. "La Alameda de Osuna: una villa suburbana». Revista Estudios Pro-Arte, 1975 , n. ${ }^{\circ}$ 2, p. 9.

19. Fernández-Quintanilla, Paloma. La IX Duquesa de Osuna, una ilustrada en la Corte de Carlos III. Aranjuez: Ediciones Doce Calles, 2017, p. 75. Sobre la biblioteca de los Osuna y su influencia en la conformación del jardín de El Capricho, consúltese Pérez Hernández, María Isabel. La casa de campo de la Alameda de la Condesa Duquesa de Benavente. Estudio de la influencia de una biblioteca en la concreción de una obra. Tesis doctoral. Madrid: Universidad Alfonso X el Sabio, 2013.

20. Luengo AÑón, Mónica. "El Capricho de la Alameda de Osuna». En AÑón Feliú, Carmen y Luengo AÑón, Mónica (coords.). Jardín y romanticismo. Madrid: Comunidad de Madrid, 2004, p. 75. 
Goya en 1785 a través del infante don Luis, convirtiéndose en su mecenas y encargándole retratos de su familia, en la línea de los que el pintor había realizado ya sobre la familia del infante en el palacio de Arenas de San Pedro ${ }^{21}$. Los duques establecieron una relación de gran familiaridad con Goya que queda patente en la correspondencia del artista, en la que comenta sus salidas de caza con el duque ${ }^{22}$. De hecho, siendo los Osuna el mejor ejemplo de alta nobleza ilustrada, su relación situó a Goya muy cerca de la corte. Los primeros retratos que realizó fueron del duque y la duquesa y, después, de la familia completa.

Además, hacia 1787, se han constatado recibos de pinturas destinadas al palacio de El Capricho, casi todas escenas campestres. Entre ellos se encuentran algunas de las pinturas más conocidas del artista, como El columpio o La cuca$\tilde{n} a$, que se verían completadas más tarde por seis cuadros de "composición de brujas", destinadas al gabinete personal de la duquesa, y entre los que figuran El aquelarre, el Vuelo de brujas o El conjuro. La petición de obras a Goya por parte de la duquesa continúa, documentándose posteriormente pinturas que representan la Pradera de San Isidro, la Era o el Verano y La gallina ciega. Se trata de un total de 22 obras de Goya que la duquesa tenía en el palacio de El Capricho $^{23}$. De hecho, algunos autores han señalado que Goya "casi monopolizó la pintura con que decoraron ciertos salones así como los retratos de los padres e hijos ${ }^{24}$, aunque Esteve también fue retratista de la familia. Es muy interesante el análisis que realiza al respecto Virginia Albarrán ${ }^{25}$, puesto que la relación de ambos artistas con los Osuna perduró en el tiempo y son muchos los retratos realizados a los duques, sus hijos y, posteriormente, en varias ocasiones del $\mathrm{X}$ duque, Francisco de Borja Téllez-Girón ${ }^{26}$.

Para cerrar este breve contexto histórico, cabe destacar uno de los hechos que marcó el desarrollo del proyecto del jardín de la Alameda de Osuna. El duque de Osuna murió en 1807 y al año siguiente se produjo la invasión francesa, estallando la Guerra de la Independencia. Como consecuencia, la duquesa abandonó Madrid y marchó a Cádiz, produciéndose la confiscación de la Alameda en ese mismo año. El Gobierno francés regaló la finca al general Beliard en 1809, nombrado por Joaquín Murat como gobernador de Madrid. El general

21. Atienza Hernández, Ignacio. Aristocracia, Poder y Riqueza en la España Moderna. La Casa de Osuna: siglos XV-XIX. Madrid: Editorial Siglo XXI, 1987, p. 108.

22. Muñoz Roca-Tallada, Carme. La condesa-duquesa de Benavente: una vida en unas cartas. Madrid: Espasa-Calpe, 1955.

23. AÑón Feliú, Carmen y Luengo AÑón, Mónica. El Capricho de la Alameda de Osuna. Madrid: Ayuntamiento de Madrid, 2003, pp. 92-95.

24. EzQuerra Del Bayo, Joaquín. Retratos de la familia Téllez-Girón: Novenos duques de Osuna. Madrid: Junta de Iconografía Nacional, 1934, p. 7.

25. Albarrán martín, Virginia. El desafio del blanco. Goya y Esteve, retratistas de la casa de Osuna: a propósito de la donación Alzaga. Madrid: Museo Nacional del Prado, 2017, pp. 14-31.

26. Sobre esta cuestión, véase: GLENDINNING, Nigel. Goya: la década de los caprichos (retratos 1792-1804). Madrid: Real Academia de Bellas Artes de San Fernando, 1992. 
Beliard conservó al jardinero Pierre Prevost, encargado de El Capricho, realizándose mejoras en el jardín ${ }^{27}$. Incluso se creó el camino conocido como "El Ramal», comprando nuevas tierras, posiblemente con el objetivo de crear un gran eje de conexión entre la Alameda y el Real Sitio del Buen Retiro, convertido en ciudadela por los ejércitos franceses ${ }^{28}$. Al regreso de Fernando VII, la duquesa recuperó su propiedad y dio un nuevo impulso al jardín, construyendo nuevos edificios como el Salón del Baile ${ }^{29}$.

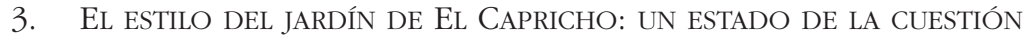

En el siglo XVIII convergieron varios tipos estilísticos en materia de jardines. Tras el fin del jardín renacentista italiano, se abrió paso al jardín francés, que fue adaptado con particularidades en cada país y ejerció un dominio absoluto durante la primera mitad del siglo XVIII ${ }^{30}$. En España, los ejemplos más destacados de jardinería clásica son el parque del Retiro ${ }^{31}$ (Madrid), los jardines del palacio de La Granja $^{32}$ (Segovia) y los de Aranjuez ${ }^{33}$. Se caracteriza por alejarse de las demandas de orden sentimental, busca efectos de perfección compositiva, en línea con el espíritu cartesiano del siglo de oro francés, que entiende el jardín como una expresión lógica, de armonía e inteligencia.

Por otro lado, cabe destacar el jardín paisajista europeo del siglo XVIII, con origen en Inglaterra. Pretendía ser una reproducción artística de la naturaleza más selecta, presentada como una sucesión de escenas que debían parecer aspectos accidentales de lo real, y donde la mano del hombre quedara razonablemente oculta, puesto que la tarea del artista era únicamente modelar los elementos de

27. PÉREZ HERNÁNDEZ, Isabel. "Los palacios urbanos y las villas suburbanas de la casa nobiliaria de Osuna en la conformación de las periferias oeste y este de Madrid». En AlBerTo Alves, Luis y García García, Francisco (coords.). V Congresso Internacional Cidades Criativas: Libro de Actas, vol. 1, 2017, p. 38 .

28. PÉrez Hernández, María Isabel. «El Ramal de El Capricho en la Alameda de Osuna. La presencia francesa en el jardín durante la Guerra de la Independencia». Anales del Instituto de Estudios Madrileños, tomo LIV. Madrid: Consejo Superior de Investigaciones Científicas, 2015, pp. 151-182.

29. NAvASCuÉs PAlacio, Pedro. "La Alameda de Osuna: una villa suburbana». Revista Estudios Pro-Arte, 1975 , n. ${ }^{\circ}$ 2, p. 19.

30. FARIELLO, Francesco. La arquitectura de los jardines. De la antigüedad al siglo XX. Barcelona: Editorial Mairea, 2004, p. 169.

31. ARIZA MuÑOZ, Carmen. Los jardines de Madrid en el siglo XIX. Madrid: Editorial Avapiés, 1988, pp. 27-35.

32. Sancho, José Luis. La Granja de San Ildefonso. Madrid: Ediciones Doce Calles, 2016.

33. Sobre los jardines de Aranjuez, con especial atención al de El Príncipe, véase: LuENGO AÑón, Mónica. Aranjuez: utopía o realidad: la construcción de un paisaje. Madrid: Consejo Superior de Investigaciones Científicas, 2008; TOVAR MARTín, Virginia. El real sitio de Aranjuez y el Arte cortesano del siglo XVIII. Catálogo de exposición. Madrid: Patrimonio Nacional, D.L., 1987. 
la naturaleza sin que su intervención fuera patente ${ }^{34}$. La nueva concepción del jardín llegó pronto a Francia y, precisamente después de la realización del Petit Trianon en Versalles, cuando el estilo paisajista se puso de moda y se difundió en las cortes europeas. El jardín paisajista supuso una revolución en el arte de la jardinería, ya que respondía a un ideal estético totalmente novedoso y a una nueva sensibilidad respecto a la naturaleza ${ }^{35}$. Además, la naturaleza en el jardín paisajista era la reflejada en la poesía, la pintura y la historia, cuya percepción suponía en el espectador una formación elitista y una sensibilidad estética ${ }^{36}$. El movimiento ilustrado será también esencial en la nueva concepción del jardín por la nueva relación entre el hombre y la naturaleza, frente a la concepción renacentista del hombre como dueño de la naturaleza. Por esta razón, se descartó el jardín clásico, puesto que implicaba el sometimiento de la naturaleza ${ }^{37}$. Otra influencia esencial en el jardín paisajista fue el influjo externo de los jardines paisajistas chinos, existentes desde la Antigüedad pero conocidos en el XVIII a través de viajeros y misioneros. Con todo ello, el jardín paisajista se convirtió en un espacio subjetivo, cuyo rasgo fundamental era la autenticidad de lo natural, donde poder liberarse de las presiones de una civilización dominada por la técnica ${ }^{38}$.

España sufrió un atraso en cuanto a la construcción de jardines según los modelos que se estaban desarrollando en otros países europeos como Inglaterra o Francia. La crisis del estilo clásico francés que se produjo en Inglaterra en el primer tercio del siglo XVIII no tuvo paralelo en España hasta el último tercio, ya que se siguieron manteniendo los postulados que habían establecido los artistas que llegaron con la nueva dinastía borbónica, en especial aquellos que habían trabajado en La Granja de San Ildefonso ${ }^{39}$. Como consecuencia, el final del siglo XVIII y los comienzos del xIX suponen una gran confusión en torno a los jardines y su estilo en España, puesto que pervivían gustos barrocos, como en el caso de la Quinta del Duque del Arco, pero también modelos neoclásicos, como el Real Jardín Botánico ${ }^{40}$.

34. ArIZA MuÑoz, Carmen. "Introducción del jardín paisajista en el Madrid del siglo XIX". Villa de Madrid, 1988, n. ${ }^{\circ}$ 97-98, p. 97.

35. Rodríguez Romero, Eva. "El jardín paisajista y la mujer en España: la Alameda de Osuna, el Casino de la Reina y Vista Alegre». En La mujer en el arte español. Actas de las VIII Jornadas de Arte (Departamento de Historia del Arte "Diego Velázquez»). Madrid: Centro de Estudios Históricos, CSIC, 1996 , p. 348.

36. ButTlar, Adrian von. Jardines del Clasicismo y el Romanticismo. El jardín paisajista. Madrid: Editorial Nerea, 1993, p. 17.

37. FARIELlO, Francesco. La arquitectura de los jardines. De la antigüedad al siglo XX. Barcelona: Editorial Mairea, 2004, p. 199.

38. Enge, Torsten Olaf y SCHRÖER, Carl Friedrich. Arquitectura de jardines en Europa (14501800). Berlín: Editorial Benedikt Taschen, 1992, p. 31.

39. Luengo AÑón, Mónica. "El Capricho de la Alameda de Osuna». En AÑón Feliú, Carmen y Luengo AÑón, Mónica (coords.). Jardín y romanticismo. Madrid: Comunidad de Madrid, 2004, p. 73.

40. ARIZA MuÑoz, Carmen. Los jardines de Madrid en el siglo XIX. Madrid: Editorial Avapiés, 1988, pp. 51-56. 
Dentro de este contexto se enmarca la construcción de El Capricho de la Alameda de Osuna, pero también del Jardín del Príncipe de Aranjuez ${ }^{41}$.

El caso que nos ocupa, como ya hemos señalado antes, ha sido definido como ejemplo de varios estilos, tanto neoclásico como romántico o paisajista. Autores como Eva Rodríguez ${ }^{42}$ han apuntado que, en realidad, se trata de tres jardines: el jardín paisajista propiamente dicho, el eje de acceso al palacio más clasicista y el jardín inferior con reminiscencias renacentistas. Si hacemos un breve repaso de lo que se ha estudiado sobre El Capricho, podremos entender la dificultad de definirlo dentro de un único estilo.

Según Pedro Navascués el jardín de la Alameda de Osuna «representa el modo más acabado de villa suburbana neoclásica que tenemos en nuestro país», considerando que se desarrolla un "programa culto", típico dentro de la corriente ilustrada y vinculado a experiencias similares en Francia ${ }^{43}$. En su artículo, unas páginas después, señala que el Jardín del Príncipe de Aranjuez constituye, junto con la Alameda, los primeros ejemplos de jardín inglés en España. Este autor también reconoce zonas del jardín donde se aprecian "acentos franceses» en el trazado de líneas rectas y en el carácter bajo, recortado y geométrico de los parterres. El jardín inglés da como resultado, según Navascués, una "naturaleza caricaturizada", acentuada por las arquitecturas de jardín propias de este, como templetes o fortificaciones ${ }^{44}$.

El artículo de Navascués constituye uno de los primeros trabajos realizados en el momento en que el Ayuntamiento de Madrid adquirió El Capricho y comenzaban las obras de restauración, con el consiguiente interés despertado en toda una serie de investigadores de este ámbito. Consideramos que la definición de El Capricho como villa suburbana neoclásica es demasiado escueta para definir la complejidad arquitectónica y estilística de este espacio. La utilización de temas clásicos no encaja plenamente con el sentido del Neoclasicismo, puesto que no existe orden en sus formas, sino que se utilizan temas clásicos para crear un espacio donde el espectador que pasea se encuentre diversos elementos arquitectónicos sorprendentes. Sí estamos de acuerdo con su apunte sobre los tintes franceses de

41. Sobre el caso de Aranjuez véase: Luengo AÑón, Mónica. Aranjuez: utopía o realidad: la construcción de un paisaje. Madrid: Consejo Superior de Investigaciones Científicas, 2008; SANCHO, José Luis. "El Real Sitio de Aranjuez y el arte del jardín bajo en el reinado de Carlos III". Reales Sitios, 1998, n. ${ }^{\circ}$ 98, pp. 37-44; TOVAR MarTín, Virginia. El real sitio de Aranjuez y el Arte cortesano del siglo XVIII. Catálogo de exposición. Madrid: Patrimonio Nacional, D.L., 1987.

42. Rodríguez Romero, Eva. «El jardín paisajista y la mujer en España: la Alameda de Osuna, el Casino de la Reina y Vista Alegre». En La mujer en el arte español. Actas de las VIII Jornadas de Arte (Departamento de Historia del Arte "Diego Velázquez»). Madrid: Centro de Estudios Históricos, CSIC, 1996, p. 354.

43. NAvascuÉs PAlacio, Pedro. "La Alameda de Osuna: una villa suburbana». Revista Estudios Pro-Arte, 1975, n. $^{\circ}$ 2, pp. 7-8.

44. NAvascués Palacio, Pedro. "La Alameda de Osuna: una villa suburbana». Revista Estudios Pro-Arte, 1975 , n. ${ }^{\circ}$ 2, p. 11. 
algunos trazados frente a otra zona donde encontramos el jardín inglés o paisajista propiamente dicho.

Unos años después, el jardín de El Capricho fue analizado por Carmen Añón, una de las autoras que más estudios ha dedicado a este jardín, señalando que es «un reflejo exacto de las tendencias paisajísticas de ese momento, con muy pocos años de retraso conceptual en comparación con lo que se estaba haciendo en el resto de Europa $"{ }^{45}$. Esta autora considera que es también un jardín "femenino por esencia ${ }^{46}$, puesto que está hecho por una mujer ilustrada de gran sensibilidad y cultura que ha viajado por Europa y está al tanto de todas las novedades. Según C. Añón este jardín será en su esencia el jardín romántico de la duquesa y sus descendientes, aunque también diferencia en él diversas partes, unas caracterizadas por los principios del jardín clásico y otras por el paisajista.

Posteriormente, Eva Rodríguez definió El Capricho como el "primer jardín netamente paisajista, con un programa completo de pequeñas arquitecturas que iban articulando las diversas escenas y eran los focos o los altos en diversos recorridos ${ }^{47}$. Coincide con la apreciación de Carmen Añón en valorar la influencia fundamental de la impulsora del proyecto de El Capricho, por ello señala que su huella es tan evidente que las trasformaciones posteriores no alterarán en su esencia. Podemos pensar que existe una cierta indefinición por parte de E. Rodríguez a la hora de determinar el estilo del jardín de la Alameda de Osuna, pero esta autora distingue también varias partes en él, siendo solamente una propiamente paisajista, y otras más vinculadas con el clasicismo ${ }^{48}$. La concepción paisajista y romántica de E. Rodríguez se justifica también porque, debido a la relación de la duquesa con las Sociedades de Amigos del País, la Alameda participó en los proyectos fisiocráticos, por ejemplo con el cultivo de especies de otras regiones.

Carmen Ariza $^{49}$ concibe El Capricho como «el primer jardín romántico de España, junto con el reducto paisajista de Juan de Villanueva hiciera en el Jardín del Príncipe de Aranjuez», especificando después que «sería más exacto calificarlo de

45. AÑón Feliú, Carmen. "El Capricho» de la Alameda de Osuna. Madrid: Fundación Caja de Madrid, 1994, p. 27.

46. AÑón Feliú, Carmen. "El Capricho" de la Alameda de Osuna. Madrid: Fundación Caja de Madrid, 1994, p. 33.

47. Rodríguez Romero, Eva. "El jardín paisajista y la mujer en España: la Alameda de Osuna, el Casino de la Reina y Vista Alegre». En La mujer en el arte español. Actas de las VIII Jornadas de Arte (Departamento de Historia del Arte "Diego Velázquez»). Madrid: Centro de Estudios Históricos, CSIC, 1996 , p. 353.

48. Rodríguez Romero, Eva. «El jardín paisajista y la mujer en España: la Alameda de Osuna, el Casino de la Reina y Vista Alegre». En La mujer en el arte español. Actas de las VIII Jornadas de Arte (Departamento de Historia del Arte "Diego Velázquez»). Madrid: Centro de Estudios Históricos, CSIC, 1996 , p. 354.

49. ARIZA MuÑOz, Carmen. Jardines de Madrid: paseos arbolados, plazas y parques. Barcelona: Editorial Lunwerg, 2001, p. 376. 
jardín mixto ${ }^{50}$. Por su parte, Mónica Luengo ${ }^{51}$ lo concibe como prototipo de jardín romántico, aunque reconozca que no se pueda clasificar como tal cronológicamente. Argumenta al respecto que es necesario tener en cuenta la consideración de la mirada y de la historia, estableciendo que no hay tanto jardines románticos como jardines considerados románticos. Ello implicaría que esta definición no dependería tanto de las obras de arte, es decir, el jardín, como de la mirada del espectador y en la imagen que la historia nos ha ofrecido de ellas. De este modo, según esta autora, existirían jardines que, sin ser en su origen románticos, el devenir histórico los ha recubierto de un halo romántico que hace que los consideramos como tales.

Por otra parte, se ha señalado que ha sido su propia historia lo que ha rodeado el jardín de El Capricho de un halo especial que ha trascendido y transformado lo que fue un «jardín de ideas, ${ }^{52}$ en un «jardín de sentimientos ${ }^{53}$. Sin embargo, Mónica Luengo sitúa El Capricho y el Jardín del Príncipe de Aranjuez como los únicos ejemplos de lo que ella denomina "paisajismo a la española", es decir, el resultado de intentar adaptar los principios del jardín ingles al clima, la topografía y la peculiar idiosincrasia española. Estos principios teóricos y prácticos vendrán, además, tamizados a través de un filtro francés en el que también se confunden con reminiscencias del jardín rococó y nuevos aires prerrománticos ${ }^{54}$.

Teniendo en cuenta todos estos trabajos, podemos indicar que es destacable el uso indistinto de los términos paisajista y romántico, lo cual nos conduce a preguntarnos el porqué de esta confusión de conceptos. Cronológicamente debemos esperar al siglo XIx para encontrar el Romanticismo, pero en este siglo los jardines vuelven por lo general a los esquemas clasicistas y geométricos que se alejan del paisajismo y, por tanto, de las emociones que podríamos calificar como románticos, aunque también se afianza un tipo de jardín compuesto que, en cualquier caso, deja fuera elementos sentimentales ${ }^{55}$. Por ello, considero que calificar un jardín de romántico supone un anacronismo, es decir, aplicar un concepto propio de un movimiento del XIX a una realidad del XVIII.

Consideramos que en el jardín de El Capricho se superponen estilos y tendencias, pudiendo definirlo como un jardín ecléctico donde se combina y sintetiza

50. ARIZA MuÑoz, Carmen. Jardines de Madrid: paseos arbolados, plazas y parques. Barcelona: Editorial Lunwerg, 2001, p. 380.

51. Luengo AÑón, Mónica. "El Capricho de la Alameda de Osuna». En AÑón Feliú, Carmen y Luengo AÑón, Mónica (coords.). Jardín y romanticismo. Madrid: Comunidad de Madrid, 2004, p. 71.

52. Remón MenÉndeZ, Juan. "The Alameda of The Duchess of Osuna: A Garden of Ideas". Journal of Garden History, 1993, vol. 13, pp. 224-225.

53. Luengo AÑón, Mónica. "El Capricho de la Alameda de Osuna». En AÑón Feliú, Carmen y LuENGo AÑón, Mónica (coords.). Jardín y romanticismo. Madrid: Comunidad de Madrid, 2004, p. 72.

54. Luengo AÑón, Mónica. "El Capricho de la Alameda de Osuna». En AÑón Feliú, Carmen y LuEngo AÑón, Mónica (coords.). Jardín y romanticismo. Madrid: Comunidad de Madrid, 2004, p. 73.

55. FARIELLO, Francesco. La arquitectura de los jardines. De la antigüedad al siglo XX. Barcelona: Editorial Mairea, 2004, p. 245. 
el jardín clásico en su sentido de orden, y un jardín paisajista, con un poderoso discurso naturalista y pintoresco que sigue la línea de las últimas tendencias en Europa, especialmente en relación al jardín inglés (llamado después paisajista), que se difundirá desde Inglaterra. Se trata, al fin y al cabo, de un jardín que posee el sello de la personalidad de la duquesa, puesto que se corresponde con su contexto particular, marcado por su gran formación intelectual e inquietudes culturales, a la orden de las novedades europeas, pero también por el amplio círculo de amistades y el poder económico que poseía, convirtiéndose además en una de las mujeres pioneras en tomar medidas enmarcadas en el movimiento ilustrado ${ }^{56}$. La duquesa se empapó de las ideas en torno al paisaje y la nueva concepción de la naturaleza de autores como Rousseau, Milton, Goethe o el español Pedro Montengón. Por ello, a pesar de este sello personal, como ya hemos apuntado, este jardín está en la línea de los jardines paisajistas europeos del XVIII, siendo el primero en España junto al Jardín del Príncipe de Aranjuez.

\section{El proyecto de la Alameda de Osuna}

El futuro jardín de la Alameda de Osuna, antes de pasar a manos de los duques de Osuna en 1778, estaba formado por una serie de huertas y edificios que eran propiedad del conde de Priego ${ }^{57}$. A partir de su adquisición, este espacio fue ensanchando sus límites hasta alcanzar una superficie de 250 hectáreas, de las cuales se dedicarían 19 al jardín, mientras que el resto de la posesión se dedicó a poner en práctica las novedosas ideas reformistas de la duquesa ${ }^{58}$. No pretendían únicamente crear un jardín de gran belleza, sino organizar su espacio según principios fisiocráticos mediante la construcción de viveros, huertas e invernaderos donde aplicar las novedades ${ }^{59}$. La vivienda existente en el terreno fue el origen del palacio de la duquesa, siendo reformado por los arquitectos que intervinieron en la construcción de la finca. Entre ellos estaban los mejores de la época, como Mateo Guill, Manuel Machuca o Mateo Medina. En general, se decantaron por una

56. El interés de la duquesa en formar parte de la Sociedad Económica Matritense, presidida por su marido, cristalizó en la creación de la Sociedad de Damas de Honor y Mérito, de la cual fue la primera presidenta. Sobre esta cuestión, consúltese: Crespo Delgado, Daniel. Árboles para una capital. Árboles en el Madrid de la Ilustración. Aranjuez: Ediciones Doce Calles, 2012, pp. 136-145.

57. PÉrEZ HERnÁNDEZ, Isabel. "Los palacios urbanos y las villas suburbanas de la casa nobiliaria de Osuna en la conformación de las periferias oeste y este de Madrid». En AlBerTo Alves, Luis y García García, Francisco (coords.). V Congresso Internacional Cidades Criativas: Libro de Actas, vol. 1,2017 , p. 38.

58. Luengo AÑón, Mónica. «El Capricho de la Alameda de Osuna». En AÑón Feliú, Carmen y LuEngo AÑón, Mónica (coords.). Jardín y romanticismo. Madrid: Comunidad de Madrid, 2004, p. 77.

59. Fernández-Quintanilla, Paloma. La IX Duquesa de Osuna, una ilustrada en la Corte de Carlos III. Aranjuez: Ediciones Doce Calles, 2017, pp. 113-114. 
renovación de la arquitectura desde la Academia de Bellas Artes de San Fernando, institución en la que casi todos ocuparon puestos destacados ${ }^{60}$.

Sin embargo, los principales artífices del proyecto de El Capricho fueron artistas y arquitectos franceses e italianos. El primer proyecto para el jardín de la Alameda fue llevado a cabo por Pablo Boutelou desde finales del año 1784, de una familia de jardineros franceses que habían llegado a España con los primeros Borbones para trabajar en los jardines de La Granja ${ }^{61}$. Aunque Boutelou desaparece de los archivos de los duques poco después, las excavaciones realizadas para la restauración del jardín han mostrado que una parte importante del jardín fue construido según el proyecto de Boutelou, especialmente la zona del jardín más próximo al palacio, conocida como "Jardín Bajo». Boutelou fue sustituido probablemente por una cuestión de "exclusividad", ya que trabajaba también en Aranjuez para la Casa Real y es posible que la duquesa no quisiera compartir sus servicios con la reina María Luisa.

A partir de 1787, la duquesa de Osuna contrató a Jean Baptiste Mulot ${ }^{62}$, que había trabajado en Versalles, concretamente en el Petit Trianon de María Antonieta, obra que constituye uno de los principales paralelos europeos de El Capricho. También había viajado por Holanda e Inglaterra, visitando los últimos jardines y conociendo, de este modo, las novedades paisajistas, lo cual le convertía en la persona adecuada para desarrollar un proyecto paisajista. En su contrato, la duquesa exigía que no trabajase para ninguna otra persona y recibiría las órdenes directamente de ella. No conocemos con exactitud cuál fue su actuación en la Alameda, pero durante este periodo se realizaron importantes obras como el jardín de la Fuente de las Ranas o el Templete de $\mathrm{Baco}^{63}$. Sin embargo, Mulot fue sustituido tres años después de su llegada por otro jardinero francés, Pedro Prevost ${ }^{64}$.

En este contexto encontramos también otra figura que será determinante para llevar a cabo el proyecto de El Capricho. Se trata de Ángel María Tadey y

60. Luengo AÑón, Mónica. «El Capricho de la Alameda de Osuna». En AÑón Feliú, Carmen y Luengo AÑón, Mónica (coords.). Jardín y romanticismo. Madrid: Comunidad de Madrid, 2004, p. 78.

61. La familia Boutelou constituyó una saga de jardineros de renombre, que desarrolló su actividad en París y en Madrid, estando presente también en Aranjuez, donde Esteban Boutelou fue jardinero mayor del Sitio Real de Aranjuez. Sobre este aspecto: Crespo Delgado, Daniel. Árboles para una capital. Árboles en el Madrid de la Ilustración. Aranjuez: Ediciones Doce Calles, 2012, pp. 130-133. Por otro lado, es preciso destacar que los hermanos Claudio y Esteban Boutelou fueron pensionados en Inglaterra durante la década de los 90 del siglo XVIII. A su regreso, aplicaron directamente muchos de sus aprendizajes en los campos y jardines españoles. Véase García Pereda, Ignacio. "Los jardines y la agricultura de Inglaterra. Tres pensionados españoles en la década de 1790». Bouteloua, 2013, n. ${ }^{\circ}$ 15 , pp. 76-87.

62. AriZa MuÑoz, Carmen. Los jardines de Madrid en el siglo XIX. Madrid: Editorial Avapiés, 1988 , p. 45.

63. AÑón Feliú, Carmen. "El Capricho" de la Alameda de Osuna. Madrid: Fundación Caja de Madrid, 1994, p. 30.

64. Luengo AÑón, Mónica. "El Capricho de la Alameda de Osuna». En AÑón Feliú, Carmen y Luengo AÑón, Mónica (coords.). Jardín y romanticismo. Madrid: Comunidad de Madrid, 2004, p. 79. 
Borghini $^{65}$, un decorador originario del norte de Italia, procedente de una familia dedicada a esta labor, que fue contratado para trabajar en la Alameda hasta $1829^{66}$. Se trata de un artista polifacético, puesto que es escenógrafo, maestro teatrista y un personaje clave que ejerció de maestro de ceremonias, decorador de interiores, especialmente para crear los decorados necesarios para la celebración de fiestas, administrador, arquitecto y pintor. En consecuencia, estableció una estrecha relación con la duquesa. Así, la actuación de Ángel María Tadey fue esencial para convertir el jardín de El Capricho en un gran escenario con decorados donde poner en escena algunas de las ideas de la duquesa.

En este sentido, Carmen Añón señala que su intervención fue esencial para contribuir al carácter paisajista del jardín de la Alameda ${ }^{67}$. Finalmente, en 1795 , el jardinero francés Pedro Prevost ${ }^{68}$ entró al servicio de la duquesa, siguiendo las mismas condiciones que anteriormente tuvo Mulot, aunque murió en 1810 durante la ocupación francesa. Con la intervención de estos jardineros y artistas, desde 1783 hasta 1808, se gestó la estructura básica del jardín. Este se articula en tres niveles diferentes. El eje principal conduce a la fachada posterior del palacio, pasando por la llamada "plaza de los emperadores". Al norte se extiende el jardín que podríamos definir como plenamente paisajista, con un trazado libre e irregular, mientras que al sur encontramos el laberinto y la zona de los invernaderos.

Otras aportaciones posteriores, realizadas tras la muerte de la duquesa por arquitectos destacados de la Academia de Bellas Artes de San Fernando como Martín López Aguado ${ }^{69}$, enriquecieron la composición de El Capricho, aunque prevalecerá el sello personal de la duquesa. Por esta razón, no analizaremos este periodo, sino que nos centraremos en aquellas obras realizadas bajo la dirección de la IX duquesa de Osuna, puesto que es su interés e inquietud ilustrada la que nos interesa analizar en relación a la recepción de los temas clásicos en las arquitecturas del jardín.

65. La celebración de fiestas dentro del ambiente cortesano requería la creación de escenarios y estructuras efímeras para su desarrollo. Teatristas y decoradores como Ángel María Tadey eran los artífices de tales escenarios festivos, como hemos visto anteriormente en el caso de la celebración llevada a cabo por los duques de Osuna en honor de Carlos IV: MARTínez MEDINA, África. "La vivienda aristocrática, escenario de la fiesta: festejos realizados por los Condes-Duques de Benavente con motivo de la exaltación al trono de Carlos IV, 19 de enero de 1789". En Romero FerRer, Alberto (coord.). De la Ilustración al romanticismo 1750-1850: VI encuentro "Juego, fiesta y transgresión» (Cádiz 16, 17 y 18 de octubre de 1991). Editorial Árbol académico, 1995, pp. 309-317.

66. Luengo AÑón, Mónica. "El Capricho de la Alameda de Osuna». En AÑón Feliú, Carmen y Luengo AÑón, Mónica (coords.). Jardín y romanticismo. Madrid: Comunidad de Madrid, 2004, p. 78.

67. AÑón Feliú, Carmen. "El Capricho" de la Alameda de Osuna. Madrid: Fundación Caja de Madrid, 1994, p. 32.

68. ARIZA MuÑoz, Carmen. Los jardines de Madrid en el siglo XIX. Madrid: Editorial Avapiés, 1988, pp. 45-46.

69. ÍÑIguEZ, Francisco. "El arquitecto Martín López Aguado y la Alameda de Osuna». Archivo Español de Arte, tomo 18, n. ${ }^{\circ} 70,1945$, pp. 219-228. 


\subsection{La plaza de los emperadores y la exedra de la IX duquesa de Osuna}

La plaza de los emperadores se encuentra en el eje principal de ingreso a la fachada posterior del palacio (Fig. 1). Los bustos de los doce Césares de las Vita Caesarum (desde Julio César a Domiciano) del historiador romano Suetonio fueron colocados en 1815, pero estuvieron en Gandía, otro ducado de la duquesa de Osuna, desde finales del siglo XVII. Fueron enviados desde Roma, según se ha comprobado en la documentación de archivo al respecto ${ }^{70}$, y guardados en Gandía hasta que la duquesa conoció su existencia y pidió que fuesen enviadas a la Alameda. Sin embargo, Carmen Ariza ${ }^{71}$, siguiendo a Pedro Navascués, señala que pudieron haberse traído desde la casa-palacio que los duques de Osuna tenían en Leganitos. No tenemos mucha información sobre estas esculturas, pero sí podemos enmarcarlas en toda una corriente de coleccionismo de series de bustos de los doce emperadores de Suetonio que fue frecuente a partir de los estudios sobre la obra en el Renacimiento y la numismática asociada a dichos emperadores.

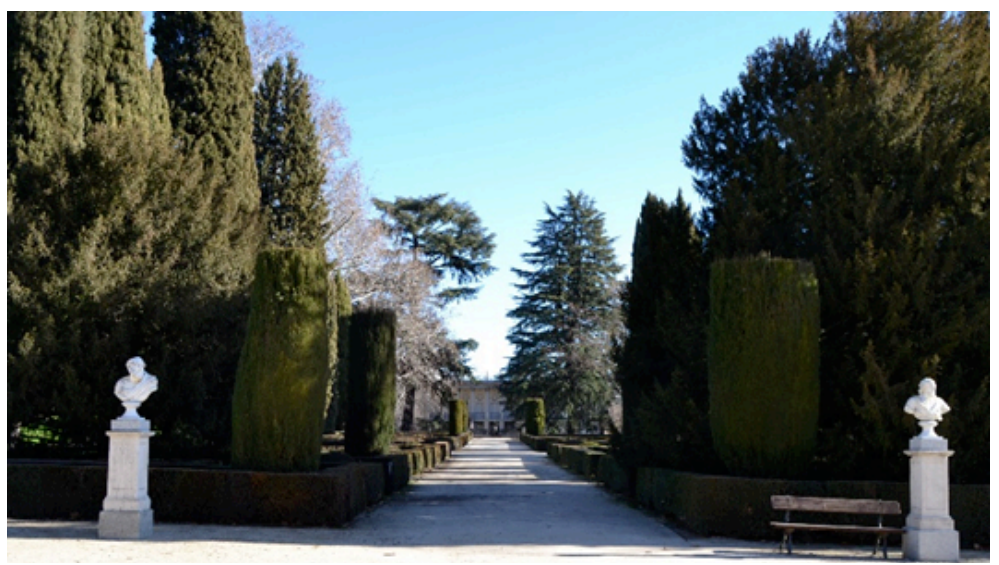

Fig. 1. Plaza de los emperadores. Fuente: realización propia.

En este sentido, cabe destacar que los doce Césares fueron considerados por unos como el máximo ejemplo del soberano modélico y por otros, por el contrario, como gobernantes detestables ${ }^{72}$. Su exposición en espacios de poder, como palacios reales o aristocráticos, permite que lo interpretemos como un

70. AÑón Feliú, Carmen. "El Capricho" de la Alameda de Osuna. Madrid: Fundación Caja de Madrid, 1994, p. 38.

71. ARIZA MuÑoz, Carmen. Jardines de Madrid: paseos arbolados, plazas y parques. Barcelona: Editorial Lunwerg, 2001, p. 380.

72. SCHrÖDER, Stephan. "Las series de los Doce Emperadores». En AA. VV. El coleccionismo de escultura clásica en España. Madrid: Museo del Prado, 2001, p. 43. 
intento de vinculación con gobernantes de la Antigüedad que otorgarían prestigio y mostrarían virtudes del «buen gobernante». La iconografía era conocida a través de las monedas romanas, donde aparecía su imagen y leyendas asociadas. A partir del siglo XIV, estas monedas fueron utilizadas para ilustrar las ediciones de la obra de Suetonio ${ }^{73}$.

Sin embargo, en la segunda mitad del siglo XV, a la hora de crear esculturas de bulto redondo, se planteó la cuestión de cómo representar a los emperadores de frente, ya que las monedas reproducen solo los perfiles y los retratos antiguos de mármol aún no estaban plenamente identificados. Como consecuencia, hasta el siglo XVII, las series de los doce Césares presentan fallos y no todos los emperadores tienen los mismos rasgos que hoy aceptamos como auténticos ${ }^{74}$. La mayoría de series no están formadas por esculturas antiguas originales, sino obras de escultores del Renacimiento italiano. En España, Felipe II poseyó varias series de los doce Césares, conservándose en la actualidad algunas obras en el Museo del Prado y en el Palacio Real.

En el caso del jardín de la Alameda de Osuna, el significado de crear una plaza en la que estuvieran presentes las esculturas de los doce emperadores romanos del relato de Suetonio adquiere un significado impreciso, puesto que se trata de un ámbito privado de recreo que, a su vez, constituyó un espacio de reunión de la nobleza cortesana. La proximidad a dicho ambiente cortesano, cercano a la familia real, puede explicar el significado de la creación de esta plaza donde, a través de la presencia de los emperadores romanos cuyas vidas son relatadas por Suetonio en su obra, quedaran plasmadas las virtudes del buen gobernante. Se trataría, en definitiva, de un espacio de autorrepresentación y vinculación con la monarquía. Las imágenes de estos gobernantes constituyeron un símbolo de legitimidad para todos aquellos Estados modernos que se consideraban herederos del Imperio romano ${ }^{75}$.

Por otro lado, en esta plaza también se encuentra una exedra dedicada a la IX duquesa de Osuna por su nieto y heredero D. Pedro Alcántara Téllez Girón (Fig. 2). Aunque la cronología de su construcción se sitúa fuera de nuestro periodo de análisis, sí debemos señalar algunas ideas al respecto, puesto que es un monumento donde se incorporan muchos elementos clásicos. Se trata de un templete construido hacia $1838^{76}$ formado por cuatro columnas de mármol de orden jónico que sostenían una semicúpula decorada con casetones que hoy está perdida pero conocemos por fotografías antiguas. El conjunto se completa con esculturas clasicistas, esfinges y leones, en plomo y mármol. En el centro de la construcción

73. HaSkell, Francis. La bistoria y sus imágenes. Madrid: Alianza Editorial, 1994, p. 25.

74. SchröDER, Stephan. "Las series de los Doce Emperadores». En AA. VV. El coleccionismo de escultura clásica en España. Madrid: Museo del Prado, 2001, p. 43.

75. Elvira Barba, Miguel Ángel. Arte y mito. Manual de iconografía clásica. Madrid: Ediciones Sílex, 2013, p. 544.

76. ARIZA MuÑoz, Carmen. Jardines de Madrid: paseos arbolados, plazas y parques. Barcelona: Editorial Lunwerg, 2001, p. 380. 
encontramos un busto de la duquesa en bronce, realizado por José Tomás ${ }^{77}$, con una inscripción en su honor. Al templete se accede mediante una escalinata dividida en dos tramos, situándose en el primer tramo siete esfinges vaciadas en plomo por Francisco de Elías. En los laterales del templete encontramos dos esculturas clasicistas de mármol blanco sobre pedestales de piedra de Colmenar, alternadas con leones y jarrones de plomo.

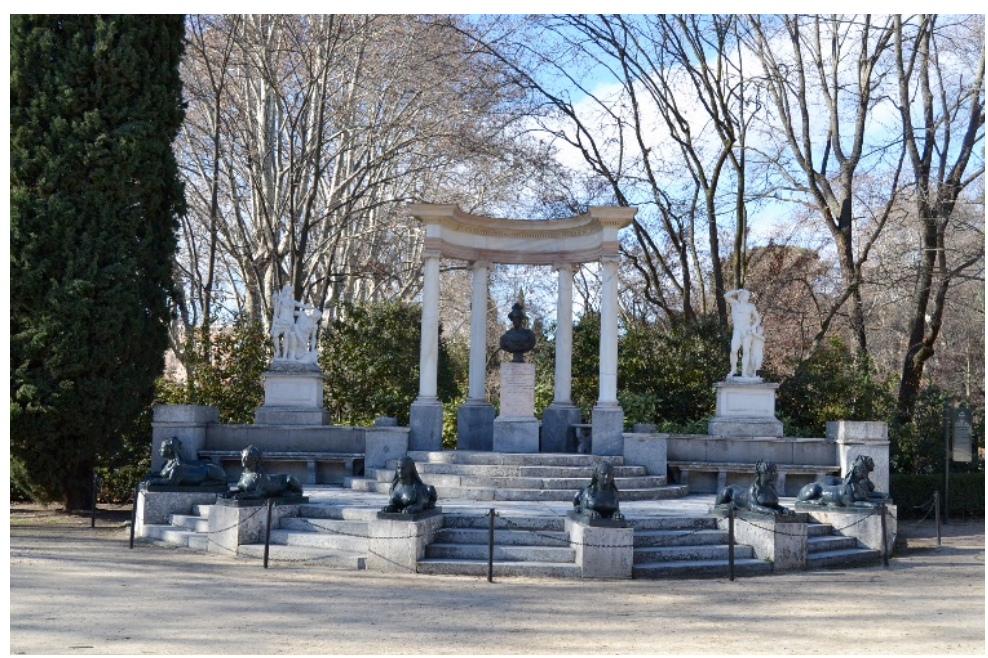

Fig. 2. Exedra de la IX duquesa de Osuna. Fuente: realización propia.

El análisis de este monumento resulta confuso, puesto que Carmen Añón ${ }^{78}$ ha apuntado que hay notas que nos permitirían situarlo entre 1787 y 1792, albergando una fuente y atribuido a Ángel María Tadey, pero Madoz atribuye la obra a Martín López Aguado ${ }^{79}$. De este modo, parece que lo más lógico sería pensar que la exedra existía con anterioridad pero que Pedro Alcántara Téllez Girón, que heredó la Alameda por la temprana muerte de sus padres, al fallecimiento de su abuela querría rendir homenaje a la creadora del conjunto. En cualquier caso, resulta enormemente significativo el emplazamiento de esta exedra con el busto de la IX duquesa de Osuna en el mismo espacio que los bustos de los doce

77. AÑón Feliú, Carmen. "El Capricho» de la Alameda de Osuna. Madrid: Fundación Caja de Madrid, 1994, p. 39.

78. AÑón FELIÚ, Carmen. "El Capricho" de la Alameda de Osuna. Madrid: Fundación Caja de Madrid, 1994, p. 39.

79. Nos referimos a la siguiente obra: MADOZ, Pascual. Diccionario geográfico-estadísticobistórico de España y sus posesiones de Ultramar. Madrid. Se ha consultado la copia digital disponible en: http://www.bibliotecavirtualdeandalucia.es/catalogo/consulta/registro.cmd?id=6353. 
Césares de la Vita Caesarum. En primer lugar, el hecho de que aparezca rodeada de elementos arquitectónicos clasicistas, como las columnas de orden jónico y las diversas esculturas que completan el conjunto, establece una relación clara con el conjunto de bustos. La duquesa es incluida en el espacio de representación de la monarquía y sus virtudes, siendo parte integrante de él. Consideramos que ello puede ser interpretado como una muestra o forma de representación de su poder en el ambiente cortesano de finales del siglo XVIII y comienzos del XIX.

\subsection{La fachada del palacio}

El palacio de la Alameda de Osuna no puede ser visitado en la actualidad, pero conocemos muchas de las obras que albergaba en su interior, así como su estructura, gracias a inventarios antiguos. Su interior estaba ricamente decorado y contenía pinturas de Goya como La pradera de San Isidro. La fachada urbana del palacio carece de elementos a destacar en este análisis de temas clásicos en el programa iconográfico de El Capricho. Nos interesa particularmente la fachada trasera del palacio, definida como "palladiana» por Carmen Ariza ${ }^{80}$, que se corresponde con el conocido "Jardín Bajo», clasificado dentro de los jardines italianos ${ }^{81}$, donde encontramos la llamada "Fuente de las Ranas", que desempeña el papel de giardino segreto, más íntimo y con una traza cruciforme en torno a la fuente central, rodeada de plátanos y setos (Fig. 3).

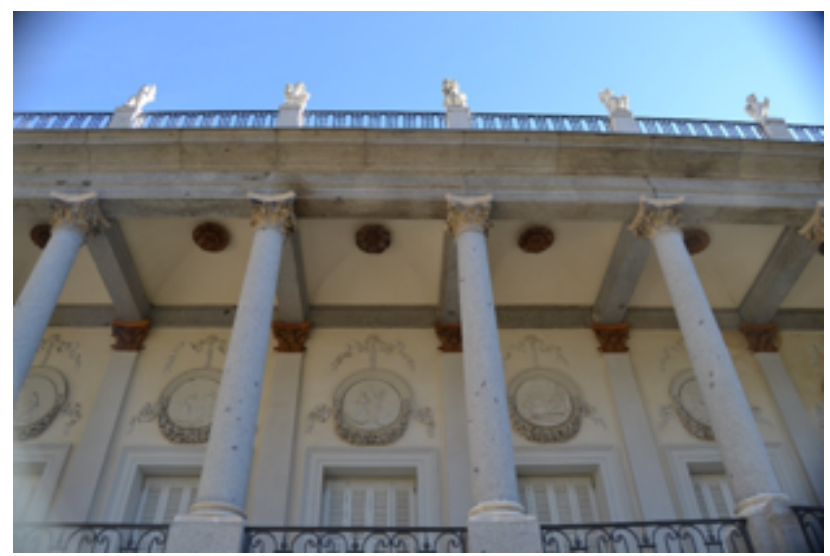

Fig. 3. Detalle de la fachada del palacio de El Capricho. Fuente: realización propia.

80. ARIZA MuÑoz, Carmen. Jardines de Madrid: paseos arbolados, plazas y parques. Barcelona: Editorial Lunwerg, 2001, pp. 380-382.

81. FARIELLO, Francesco. La arquitectura de los jardines. De la antigüedad al siglo XX. Barcelona: Editorial Mairea, 2004, p. 245. 
Esta fachada es la única que podemos ver al visitar el jardín actualmente, puesto que la principal está situada en el exterior. Se halla abierta por medio de una galería de columnas corintias rematada por un antepecho de hierro con pequeñas esculturas clasicistas. También se completa con una doble escalinata que baja hacia el "Jardín Bajo». Originalmente, en la columnata había tres esculturas de Atenea, Venus y Hércules, hoy desaparecidas. Este palacio tiene un precedente arquitectónico en el que fue construido en Versalles, el Petit Trianon. Sobre esta cuestión, ahondaremos en el próximo punto del presente trabajo.

Lo más interesante de esta fachada son los bajorrelieves inscritos en medallones circulares que recogen varios pasajes míticos donde se representa el mito de Apolo y Dafne. En la sucesión de bajorrelieves inscritos en los medallones centrales podemos apreciar diversas escenas del mito, donde se narra cómo Apolo persigue a Dafne y esta se va convirtiendo en laurel. Estos motivos arquitectónicos son de gran belleza y, junto con las columnas corintias que los enmarcan, reflejan con claridad la presencia esencial de los temas clásicos en la arquitectura de El Capricho. La representación iconográfica del mito se multiplica a partir del Gótico, haciendo referencia a la defensa de la pureza frente a la concupiscencia, como muestran los Ovidios moralizantes ${ }^{82}$. A partir del siglo XV, ha sido un tema representado por una gran cantidad de artistas, aunque la escultura de Bernini marcó un modelo a seguir en las representaciones posteriores. Además, siendo un tema tan dinámico, no se agotó en el Neoclasicismo, sino que fue recuperado en el Romanticismo y es posible rastrearlo hasta el presente. El significado de su uso en el palacio de la Alameda de Osuna constituye un ejemplo más de la recuperación de este tema de la mitología con el objetivo de ornamentar su fachada. No consideramos que sea posible extraer una explicación simbólica de su utilización, pero sí es evidente que el jardín de El Capricho está repleto de elementos arquitectónicos y decorativos clasicistas cuyo objetivo es crear un espacio de retiro y divertimento, pero también de erudición, donde lo clásico desempeña un papel fundamental.

\subsection{El templete de Baco}

El templete de Baco es la obra de mayor relieve arquitectónico y fue construida entre 1786 y 1789 (Fig. 4). Se trata de una construcción que está en la línea de los tholos griegos y de los templos romanos de Vesta, que no fueron utilizados como referente para la creación de templos cristianos por su vinculación con el paganismo y la adopción de la basílica, pero sí recuperados sobre todo en la época moderna en relación a estos ensayos paisajistas ${ }^{83}$. A diferencia del modelo antiguo, en el caso

82. Elvira Barba, Miguel Ángel. Arte y mito. Manual de iconografía clásica. Madrid: Ediciones Sílex, 2013, p. 181.

83. Watkin, David. "La arquitectura». En Jenkyns, R. (ed.). El legado de Roma. Una nueva valoración. Barcelona: Editorial Crítica, 1995, p. 324. 
que nos ocupa, la planta es elíptica u oval y escalonada. Posee doce columnas de orden jónico sobre las que se apoya un entablamento dórico sin ningún tipo de cubrición en la actualidad. Sin embargo, sabemos que tuvo una cúpula, cuya desaparición debió ocurrir en el primer tercio del siglo XIX, a juzgar por la descripción de P. Madoz ${ }^{84}$ en su diccionario, donde no la menciona. La estructura es abierta, pero destaca la particularidad con que se resuelve la planta acudiendo al modelo barroco de la elipse, las variaciones rítmicas introducidas en los intercolumnios y el hecho de montar un entablamento dórico sobre columnas jónicas ${ }^{85}$.

Por otro lado, los intercolumnios de los ejes centrales son separados por un mayor espacio para permitir una mejor visión de la escultura ${ }^{86}$. Ello no hace que pierda su esbeltez, puesto que posee unas dimensiones considerables y se sitúa sobre un pequeño promontorio. Dentro del templete encontramos una escultura de Baco en mármol, de factura bastante mediocre. Normalmente en este tipo de templos se sitúa una escultura de Venus y, de hecho, esta existió, pero fue trasladada al salón central de lo que conocemos como "Abejero", pero desconocemos el motivo del cambio. No sabemos con seguridad qué arquitecto se encargó de su trazado, pero por su fecha de ejecución se podría atribuir a Mulot o Mateo Medina ${ }^{87}$. Los capiteles y la escultura de Baco los realizó José Guerra, que también colaboró en los adornos para una estatua de Venus, aunque ignoramos si se trata de la realizada por Juan Adán que fue situada en el Abejero.



Fig. 4. Interior del templo de Baco. Fuente: realización propia.

84. Madoz, Pascual. Diccionario geográfico-estadístico-histórico de España y sus posesiones de Ultramar. Madrid. (Se ha consultado la copia digital realizada por la Biblioteca de Andalucía. Disponible en: http://www.bibliotecavirtualdeandalucia.es/catalogo/consulta/registro.cmd?id=6353).

85. NAvascuÉs Palacio, Pedro. "La Alameda de Osuna: una villa suburbana». Revista Estudios Pro-Arte, 1975 , n. ${ }^{\circ}$ 2, p. 11.

86. AÑón Feliú, Carmen. "El Capricho" de la Alameda de Osuna. Madrid: Fundación Caja de Madrid, 1994, p. 77.

87. AÑón Feliú, Carmen. "El Capricho" de la Alameda de Osuna. Madrid: Fundación Caja de Madrid, 1994, p. 75. 
La imagen del dios Baco (Dioniso) cambia durante la época antigua hasta quedar fijada en el Clasicismo griego. Mientras que en el arte griego arcaico es representado como señor del teatro, con larga barba y cabellos, a veces sujeto por una cinta, túnica larga y coronado de hiedra o vid, sosteniendo una copa de vino en su mano derecha, en el arte clásico su imagen cambia radicalmente ${ }^{88}$. Entonces es representado con un aspecto juvenil e imberbe, semidesnudo y con el pelo corto. Sobre esta base, aunque con matices, queda fijada la forma de representación de Baco desde la Antigüedad. De este modo, esta imagen encaja con la escultura de El Capricho. Por otra parte, debemos tener en cuenta los elementos vegetales que completan los elementos iconográficos que caracterizan al dios Baco y también aparecen en la escultura cuyo análisis nos ocupa aquí. Se trata de elementos vegetales, en especial la vid, relacionada directamente con la función originaria del dios y símbolo de la tragedia. En este caso, comprobamos que Baco porta en sus manos sendos racimos de vid que sirven como elementos iconográficos esenciales para identificarle en su carácter y funcionalidad.

El templete de Baco constituye un elemento clásico del jardín paisajista que aporta una escena caracterizada por una visión romántica, cuya inspiración debemos buscar en el templo de Vesta en Tívoli y otros ejemplos romanos que sirvieron de modelo para la realización de este tipo de templetes circulares ${ }^{89}$. Un ejemplo notable es el Tempietto de San Pietro in Montorio de Bramante, pero dentro del ámbito de los jardines paisajistas destaca sobre todo el «templo del Amor» del Petit Trianon de Versalles, que constituye una influencia directa para El Capricho como veremos más adelante, o en el templete de Villanueva en Aranjuez ${ }^{90}$. La funcionalidad de este templete con la escultura de Baco, de clara inspiración clasicista, teniendo en cuenta su emplazamiento, en un montículo del jardín solo visible ya adentrados en él, es la de crear un lugar que genere sorpresa con la inclusión de arquitecturas de carácter particular. Se trata de uno de los rasgos que definen el jardín paisajista, es decir, la creación de un espacio donde se moldee la naturaleza y se usen los elementos clasicistas con el objetivo de crear un jardín que suscite sorpresa, inspiración y un ambiente de distensión.

\subsection{La «rueda de Saturno»}

La conocida como «rueda» o columna de Saturno (Fig. 5) se sitúa en el centro de una composición radial en el extremo norte del jardín, cerca del templete de

88. Elvira Barba, Miguel Ángel. Arte y mito. Manual de iconografía clásica. Madrid: Ediciones Sílex, 2013, p. 264.

89. Summerson, John. The Classical Language of Architecture. Londres: Thames and Hudson, 1980, p. 39.

90. Luengo AÑón, Mónica. Aranjuez: utopía o realidad: la construcción de un paisaje. Madrid: Consejo Superior de Investigaciones Científicas, 2008. 
Baco. Se trata de uno de los elementos más enigmáticos del parque. Como hemos señalado, se encuentra en el centro de una plaza radial que se abre en seis caminos de iguales proporciones rodeados de setos de boj. Desde este punto central, se singularizan dos perspectivas importantes. Por un lado, la que se abre hacia el extremo norte de la posesión y culmina con el Abejero y, por otro, la que conduce al Templete de Baco. El dibujo de este hexagrama perfecto con Saturno en su centro ha sido vinculado con el símbolo masónico conocido como «anillo de Saturno». Aunque no conocemos con exactitud el momento de su construcción, Pedro Navascués señaló la hipótesis de que la duquesa de Osuna se hubiera inspirado en las descripciones de la posesión de Château Raba, cerca de Burdeos, realizadas por un enviado personal de la duquesa, a las que acompañaba un pequeño plano que presenta un aspecto similar al de la "rueda de Saturno", con una columna central en una plaza ${ }^{91}$

Por otro lado, y dada la relación de Goya con la duquesa de Osuna y el jardín de El Capricho ${ }^{92}$, se ha señalado la influencia de su obra sobre el mismo tema de Saturno devorando a sus hijos, que el artista elaboró en su obra Saturno entre 1820 y $1823^{93}$. Como no sabemos en qué año se construyó la columna con la escultura en El Capricho, no podemos determinar con seguridad dicha influencia directa, pero sí es un detalle curioso a tener en cuenta. No son muy frecuentes las representaciones de Saturno en esta parte del mito, en el que un oráculo advierte a Cronos (Saturno en la mitología romana) que uno de sus hijos le destronaría, por lo que decidió comérselos uno a uno al nacer.

La representación iconográfica de Saturno se vincula principalmente con la identificación del dios griego Cronos, padre de Zeus, con el Saturno romano, convirtiéndose en una de las principales divinidades que gobernaron el Lacio, relacionada con el ámbito agrícola. Para que ello fuese posible, debía ser establecida una iconografía, que se inspiró en la vestimenta de los primitivos monarcas del Lacio ${ }^{94}$. Como vemos en el caso que nos ocupa, la escultura de Saturno porta un manto amplio que rodea su vientre y le cubre la cabeza, asemejándose a un sacerdote.

91. NAvascuÉs Palacio, Pedro. "La Alameda de Osuna: una villa suburbana». Revista Estudios Pro-Arte, 1975 , n. ${ }^{\circ}$ 2, p. 14.

92. Albarrán Martín, Virginia. El desafío del blanco. Goya y Esteve, retratistas de la casa de Osuna: a propósito de la donación Alzaga. Madrid: Museo Nacional del Prado, 2017; GLENDINNING, Nigel. Goya: la década de los caprichos (retratos 1792-1804). Madrid: Real Academia de Bellas Artes de San Fernando, 1992.

93. La lista de paralelos es extensa. Saturno es representado desde época antigua en diversas facetas y con una iconografía que evoluciona durante los siglos. En época moderna y tras la recuperación del valor de la mitología clásica, se representa al dios en diversas escenas de su vida. Una de las más representadas es en la que devora a sus hijos. No sólo destaca la pintura de Goya, sino que también es preciso destacar la obra de Rubens para la Torre de la Parada en Madrid (1636), para la que desarrolló una serie de pinturas mitológicas.

94. Elvira Barba, Miguel Ángel. Arte y mito. Manual de iconografía clásica. Madrid: Ediciones Sílex, 2013, pp. 54-56. 
En las representaciones antiguas también porta la hoz, como símbolo de su vinculación con la agricultura. Esta divinidad proyectaba, desde sus representaciones en la Antigüedad, un carácter taciturno y malvado.

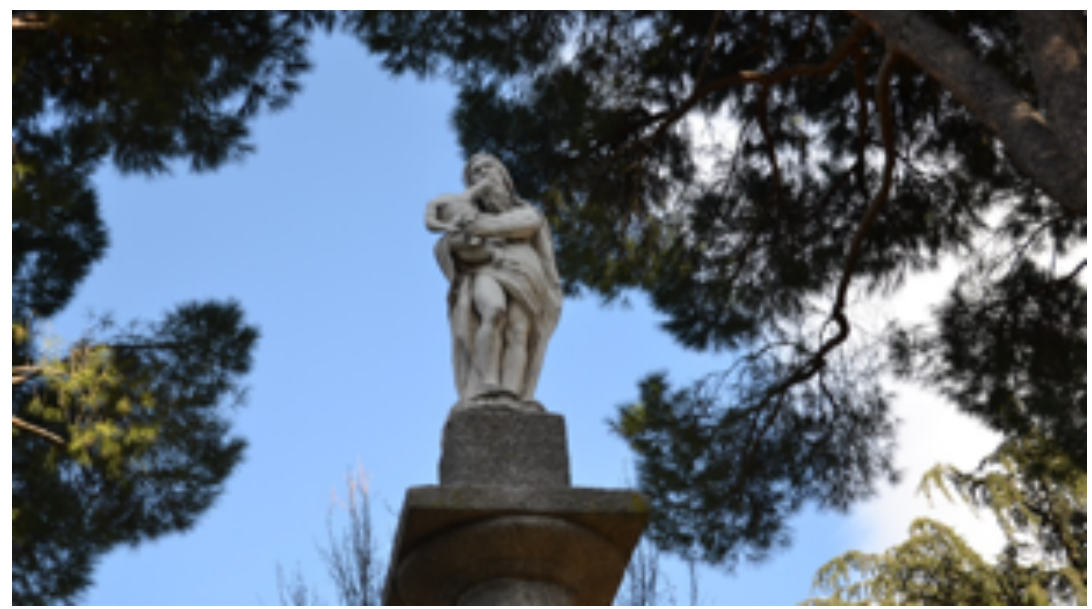

Fig. 5. Estatua de Saturno de El Capricho. Fuente: realización propia.

La escultura de Saturno se eleva sobre una columna del orden de Paestum. La utilización de este orden ha sido interpretada como una referencia, junto con el mosaico pompeyano que conocemos que existía en el comedor del palacio, a las excavaciones arqueológicas y a las ruinas descubiertas en el sur de Italia en la segunda mitad del siglo XVIII, en el especial el caso de Pompeya ${ }^{95}$. No conocemos si esta columna fue traída de Paestum ni las circunstancias o detalles de la construcción de este conjunto, lo cual no nos permite avanzar más en su interpretación dentro de la recepción de la Antigüedad en el programa iconográfico de El Capricho. Consideramos que la interpretación de la utilización de este elemento arquitectónico inspirado en el mito de Saturno debe ponerse en relación, como veíamos en el caso del templete de Baco, con la necesidad de crear diversos escenarios dentro del jardín que generaran sorpresa y admiración. La tradición clásica y sus relatos mitológicos se convirtieron, en el marco del desarrollo del jardín paisajista, en la herramienta fundamental para el desarrollo de los elementos arquitectónicos que otorgaban sentido y complementaban a la naturaleza.

95. NavascuÉs Palacio, Pedro. "La Alameda de Osuna: una villa suburbana». Revista Estudios Pro-Arte, 1975 , n. ${ }^{\circ}$ 2, p. 14. 


\subsection{El Abejero}

Se trata de un pequeño edificio formado por un cuerpo central cerrado con una cúpula, en cuyo salón central se situaba una escultura de Venus, y dos alas laterales, que terminan en pabellones, donde se encontraban los panales de abejas. Todos estos elementos están alineados de un modo muy frecuente en los casinos neoclásicos, como ocurre por ejemplo en la Casita del Príncipe de Villanueva, en El Pardo, y la de El Escorial ${ }^{96}$. Según Navascués ${ }^{97}$, el esquema arquitectónico del Abejero recuerda más al estilo rococó que al neoclásico. Dadas las similitudes con los casos de El Pardo y El Escorial, se ha señalado que sería obra de uno de los primeros arquitectos de la Alameda, como Manuel Machuca Vargas o Antonio López Aguado $^{98}$ (padre de Martín López Aguado), aunque es posible que fuese obra de Mulot. El tema del abejero era un tema de actualidad durante el siglo XVIII, llegando a existir elegantes abejeros de salón. Se trata de una tipología arquitectónica muy habitual en los jardines paisajistas, que reflejaba el interés por el acercamiento a la naturaleza, ya que a través de los cristales se podía ver la fabricación de la miel por las abejas ${ }^{99}$. Sin embargo, un edificio de esta importancia y nobleza resulta un elemento singular y único entre las arquitecturas de jardín.

Por otro lado, la fachada estaba decorada con esculturas de José Pagnucci, situadas en los nichos de la fachada principal, y con columnas en la puerta delantera y en la posterior del elemento central. La fachada posterior de las alas laterales presenta una serie de trampillas metálicas que, al alzarse, permitían la entrada de las abejas, mientras que en el interior los cristales permitían observar su actividad. En este sentido, debemos señalar que el propósito del edificio era poder contemplar, desde el interior y a través de unos vidrios, a las abejas en sus panales, en un gesto de acercamiento al orden de la Naturaleza muy propio de las corrientes ilustradas del siglo XVIII, y realizado en un edificio donde se utilizan elementos de la arquitectura clásica, aunque no con rigor, puesto que las columnas de la fachada (hoy perdidas pero que conocemos por fotografías de los años cuarenta) no son fieles a los órdenes clásicos.

También es preciso señalar que el interior de la parte central era de gran lujo, puesto que el suelo fue elaborado con mármoles italianos y en el salón se situaban ocho columnas corintias de madera estucadas con capiteles dorados y rosetones sobre un fondo azul. En el centro de este salón se encontraba la escultura de

96. AÑón Feliú, Carmen. "El Capricho" de la Alameda de Osuna. Madrid: Fundación Caja de Madrid, 1994, p. 74.

97. NAvascués Palacio, Pedro. "La Alameda de Osuna: una villa suburbana». Revista Estudios Pro-Arte, 1975 , n. ${ }^{\circ}$ 2, p. 12.

98. Navascués Palacio, Pedro. "Antonio López Aguado, Arquitecto Mayor de Madrid (17641831)». Villa de Madrid, 1971, n. ${ }^{\circ} 33$, pp. 84-89.

99. ARIZA MuÑoz, Carmen. Jardines de Madrid: paseos arbolados, plazas y parques. Barcelona: Editorial Lunwerg, 2001, p. 383. 
Venus esculpida en mármol de Carrara por Juan Adán entre 1792 y 1795, que anteriormente había estado en el Templete de Baco, y que desconocemos el motivo por el que fue trasladada al Abejero. El contraste del lujo de esta estancia se evidenciaba con el espectáculo de las colmenas que albergaban los pasillos laterales.

\section{Paralelos del JaRdín de El CAPRicho}

El principal paralelo a nivel europeo del jardín de El Capricho es el Petit Trianon de Versalles. De hecho, es el modelo que, tras recibir pronto la influencia de la nueva concepción del jardín originada en Inglaterra, difunde este estilo por Europa. La conexión entre ambos es evidente si tenemos en cuenta que, a partir de 1787, la duquesa de Osuna contrató a Jean Baptiste Mulot, que había trabajado en el Petit Trianon ${ }^{100}$. Este arquitecto había conocido las tendencias paisajistas en sus viajes y ello quedó plasmado de forma clara en ambos jardines. La monarquía absoluta francesa ejerció su influencia en toda Europa y, a pesar de su fin en 1789, Versalles, incluyendo las tendencias paisajistas que alberga, fue un modelo para el resto de países, pues no solo se trataba de copiar un tipo de jardín, sino también una forma de captación simbólica del poder que representa ${ }^{101}$.

El Petit Trianon fue construido en origen por Luis XV en Versalles, aunque su forma definitiva fue impulsada por Luis XVI para la reina María Antonieta a mediados del siglo XviII. En él destaca el llamado "templo del Amor» (Fig. 6), que constituye un claro paralelo del templete de Baco de El Capricho, pues es de inspiración clasicista en relación al tholos griego o a los templos romanos de Vesta, de planta circular y abierto en una galería de columnas, en este caso corintias. En el caso francés, la escultura que alberga el templo es de Venus. Otro paralelo francés de este tipo de templo circular lo encontramos en Méréville, un jardín adquirido en 1784 por Monsieur Joseph de Laborde. Se trata de una reconstrucción a escala original del templo de la Sibila de Tívoli, que constituye el modelo para todas estas reproducciones ${ }^{102}$. Por otro lado, y al igual que en El Capricho, donde encontramos una casa rústica conocida como "Casa de la Vieja»" ${ }^{103}$, en el conjunto del Petit Trianon también existe un espacio similar, llamado Hameau, una especie de casa rural ideal ${ }^{104}$. El objetivo de estas construcciones es despertar todo tipo de

100. AÑón Feliú, Carmen. "El Capricho" de la Alameda de Osuna. Madrid: Fundación Caja de Madrid, 1994, pp. 29-30.

101. AÑón FeLIÚ, Carmen. «El arte del jardín en la España del siglo XVIII». En El Real Sitio de Aranjuez y el Arte cortesano del siglo XVIII. Catálogo de exposición. Madrid: Patrimonio Nacional, D.L., 1987, p. 259.

102. ButTlar, Adrian von. Jardines del Clasicismo y el Romanticismo. El jardín paisajista. Madrid: Editorial Nerea, 1993, p. 108.

103. AÑón Feliú, Carmen. "El Capricho" de la Alameda de Osuna. Madrid: Fundación Caja de Madrid, 1994, p. 57.

104. ButTlar, Adrian von. Jardines del Clasicismo y el Romanticismo. El jardín paisajista. Madrid: Editorial Nerea, 1993, pp. 92-93. 
fantasías en las damas de clase alta a través de la simulación de una vida de campesina.

Dentro de España, como ya hemos señalado, el principal paralelo de El Capricho lo constituye el Jardín del Príncipe en Aranjuez. El jardinero Boutelou, que fue contratado en El Capricho y probablemente desarrolló el proyecto inicial, también desempeñó la construcción de este jardín para la corte junto a otros como Villanueva. En él también podemos diferenciar diferentes jardines al mismo tiempo, desde zonas donde encontramos un jardín clasicista hasta otras donde predomina el paisajismo, como hemos apuntado también en la Alame$\mathrm{da}^{105}$. Destacan elementos de influencia clasicista dispersos por el jardín, como, por ejemplo, el estanque chinesco con dos templetes circulares. Uno era de orden jónico y cúpula emplomada, con el fuste de las columnas en mármol negro y los capiteles en blanco, decorado con estatuas egipcias. El otro era una especie de pagoda chinesca de madera y bambú ${ }^{106}$. Sin embargo, la Alameda de Osuna constituyó el único jardín verdaderamente paisajista, puesto que el caso de Aranjuez tiene algunas reticencias ${ }^{107}$. Sin adentrarnos en más detalles por falta de espacio, creemos que queda patente no solo la existencia de paralelos de las arquitecturas de El Capricho, sino que, además, en él trabajaron los grandes arquitectos y jardineros que estaban desarrollando los trabajos punteros a nivel nacional e internacional.

\section{CONCLUSIONES}

Tras exponer el marco teórico sobre la concepción del jardín durante la época moderna y su uso de los elementos clásicos, así como del caso de El Capricho, podemos concluir varias ideas en torno a la recepción de la Antigüedad en este. Consideramos que la utilización de los temas clásicos se entiende en El Capricho en dos vías. Por una parte, son empleados desde una perspectiva muy personal por parte de la IX duquesa de Osuna, impulsora e inspiradora del proyecto, para crear un espacio de representación, distensión, reuniones intelectuales y desarrollo de toda una serie de proyectos enmarcados en la Ilustración, movimiento cultural minoritario en España pero con fuerza en algunas ciudades como Madrid. Sus proyectos también tuvieron una clara vinculación con las experiencias

105. Soto CABA, María Victoria. "Jardines de la Ilustración y el Romanticismo en España». En ButTlar, Adrian von. Jardines del Clasicismo y el Romanticismo. El jardín paisajista. Madrid: Editorial Nerea, 1993, p. 299.

106. Sото CABA, María Victoria. "Jardines de la Ilustración y el Romanticismo en España». En ButTlar, Adrian von. Jardines del Clasicismo y el Romanticismo. El jardín paisajista. Madrid: Editorial Nerea, 1993, p. 300.

107. AÑón Feliú, Carmen. "El arte del jardín en la España del siglo XVIII". En El Real Sitio de Aranjuez y el Arte cortesano del siglo XVIII. Catálogo de exposición. Madrid: Patrimonio Nacional, D.L., 1987, p. 269. 
fisiocrácticas en los terrenos anexos al jardín y el palacio de los duques. Al fin y al cabo, el sello personal que marca este jardín es evidente en la mezcla de estilos, que no podemos vincular con una única tendencia.

Sin embargo, al mismo tiempo, todos estos rasgos encajan con la corriente paisajística iniciada en Inglaterra en materia de jardines, y reflejada en otros campos de la cultura y del arte, puesto que va pareja a unos fundamentos teóricos desarrollados por los filósofos ilustrados del XVIII y también tiene reflejo en el arte. El jardín paisajista utiliza los temas clásicos para crear también un espacio que persigue el objetivo de desarrollar una reproducción artística de la naturaleza más selecta, donde la sucesión de escenas debían parecer aspectos accidentales de lo real. La modelación de la naturaleza por parte del artista no debía ser percibida, frente al jardín clásico, donde la naturaleza era un elemento de construcción más. Los elementos arquitectónicos con temas clásicos y la naturaleza son utilizados con el objetivo de exaltar la fantasía y suscitar emociones. Este concepto lo vemos claramente en El Capricho, puesto que constituye un espacio en el que los elementos arquitectónicos que recogen diferentes formas clásicas conforman una especie de escenario donde desarrollar la imaginación y las sensaciones.

Por otro lado, cabe remarcar que a España llegaron tarde estas corrientes paisajísticas en materia de jardines, al igual que lo hizo el pensamiento ilustrado. Los primeros ejemplos son el Jardín del Príncipe de Aranjuez y El Capricho. Ello se relaciona con la menor fuerza del movimiento ilustrado, puesto que, sin el impulso intelectual que fundamenta esta concepción del jardín, en España se continuó construyendo jardines clásicos. Por último, considero necesario abordar el estudio del jardín de El Capricho desde nuevas perspectivas metodológicas que aspiren a nuevos objetivos, como se ha planteado en este trabajo, en el que hemos analizado la recepción de la Antigüedad en sus elementos arquitectónicos y decorativos. Existen escasos trabajos monográficos sobre este jardín y algunas publicaciones más en las que aparece como ejemplo, pero no es analizado en profundidad. Muchos de los artículos adoptan una perspectiva desde la Historia del Arte, predominando la mera descripción de los elementos arquitectónicos. Siendo la duquesa un personaje tan interesante, inserto en las corrientes culturales e intelectuales ilustradas del momento, y El Capricho uno de los jardines más particulares de España, merece la pena profundizar las investigaciones sobre él y esperamos haber abierto un camino por el que continuar trabajando, al concebir este espacio desde una perspectiva del estudio de la Antigüedad como es la recepción de los temas clásicos durante la Ilustración.

\section{Bibliografía}

Albarrán Martín, Virginia. El desafío del blanco. Goya y Esteve, retratistas de la casa de Osuna: a propósito de la donación Alzaga. Madrid: Museo Nacional del Prado, 2017. 
AÑón Feliú, Carmen. El arte del jardín en la España del siglo XVIII. En El Real Sitio de Aranjuez y el Arte cortesano del siglo XVIII. Catálogo de exposición. Madrid: Patrimonio Nacional, D.L., 1987.

AÑón Feliú, Carmen. "El Capricho» de la Alameda de Osuna. Madrid: Fundación Caja de Madrid, 1994.

AÑóN FeLIÚ, Carmen. "Jardín: misterio, sensualidad, romanticismo y muerte». En AÑón FeLIú, Carmen y LuENGO AÑón, Mónica (coords.). Jardín y romanticismo. Madrid: Comunidad de Madrid, 2004, pp. 181-193.

AÑón Feliú, Carmen y LuENGO AÑón, Mónica. El Capricho de la Alameda de Osuna. Madrid: Ayuntamiento de Madrid, 2003.

ARIZA MuÑOZ, Carmen. "Introducción del jardín paisajista en el Madrid del siglo XIX». Villa de Madrid, 1988, n. ${ }^{\circ}$ 97-98, pp. 80-89.

ARIZA MuÑOZ, Carmen. Los jardines de Madrid en el siglo XIX. Madrid: Editorial Avapiés, 1988.

ARIZA MuÑOz, Carmen. Jardines de Madrid: paseos arbolados, plazas y parques. Barcelona: Editorial Lunwerg, 2001.

Arnaiz, José Manuel. Francisco de Goya, Cartones y Tapices. Madrid: Espasa Arte, 1987.

Atienza Hernández, Ignacio. Aristocracia, Poder y Riqueza en la España Moderna. La Casa de Osuna: siglos XV-XIX. Madrid: Editorial Siglo XXI, 1987.

Beotas López, Enrique. Los parques de Madrid. Madrid: Quindicy Editores, 1991.

Bolufer Peruga, Mónica. Mujeres e Ilustración. La construcción de la feminidad en la España del siglo XVIII. Valencia: Institución Alfonso el Magnánimo, 1998.

ButTLAR, Adrian von. Jardines del Clasicismo y el Romanticismo. El jardín paisajista. Madrid: Editorial Nerea, 1993.

CREspo Delgado, Daniel. Árboles para una capital. Árboles en el Madrid de la Ilustración. Aranjuez: Ediciones Doce Calles, 2012.

Elvira BARBA, Miguel Ángel. Arte y mito. Manual de iconografía clásica. Madrid: Ediciones Sílex, 2013.

ENGE, Torsten Olaf y SCHRÖER, Carl Friedrich. Arquitectura de jardines en Europa (14501800). Berlín: Editorial Benedikt Taschen, 1992.

EZquerRa Del BAYO, Joaquín. Retratos de la familia Téllez-Girón: Novenos duques de Osuna. Madrid: Junta de Iconografía Nacional, 1934.

FARIELLO, Francesco. La arquitectura de los jardines. De la antigüedad al siglo XX. Barcelona: Editorial Mairea, 2004

FERnÁndez Quintanilla, Paloma. La mujer ilustrada en la España del siglo XVIII. Madrid: Ministerio de Cultura, 1981.

Fernández-Quintanilla, Paloma. La IX Duquesa de Osuna, una ilustrada en la Corte de Carlos III. Aranjuez: Ediciones Doce Calles, 2017.

GARCía PEREDA, Ignacio. "Los jardines y la agricultura de Inglaterra. Tres pensionados españoles en la década de 1790». Bouteloua, 2013, n. ${ }^{\circ} 15$, pp. 76-87.

Glendinning, Nigel. Goya: la década de los caprichos (retratos 1792-1804). Madrid: Real Academia de Bellas Artes de San Fernando, 1992.

Goya en las colecciones madrileñas. Catálogo de exposición. Madrid: Fundación Amigos del Museo del Prado, 1983.

HASKELl, Francis. La historia y sus imágenes. Madrid: Alianza Editorial, 1994.

Heitzmann, Annick. «Un exemple de méthodologie versaillaise: le jardín du Pavillon frais à Trianon». En Van Ossel, Paul y Guimier-Sorbets, Anne-Marie (eds.). Archéologie des 
jardins. Analyse des espaces et méthodes d'approche. Montagnac: Éditions Monique Mergoil, 2014.

ÍNIgueZ, Francisco. "El arquitecto Martín López Aguado y la Alameda de Osuna». Archivo Español de Arte, tomo 18, n. ${ }^{\circ}$ 70, 1945, pp. 219-228.

KRuFT, Hanno-Walter. History of Architectural Theory: from Vitruvius to the present. Nueva York: Princeton Architectural Press, 1994.

Lasso de la Vega Zamora, M. Quintas de recreo. Las casas de campo de la aristocracia alrededor de Madrid. Madrid: Ayuntamiento de Madrid, pp. 117-122.

Luengo AÑón, Mónica. «El Capricho de la Alameda de Osuna». En AÑón Feliú, Carmen y LuENGO AÑón, Mónica (coords.). Jardín y romanticismo. Madrid: Comunidad de Madrid, 2004, pp. 71-89.

Luengo AÑón, Mónica. Aranjuez: utopía o realidad: la construcción de un paisaje. Madrid: Consejo Superior de Investigaciones Científicas, 2008.

Madoz, Pascual. Diccionario geográfico-estadístico-histórico de España y sus posesiones de Ultramar. Madrid. Se ha consultado la copia digital realizada por la Biblioteca de Andalucía. Disponible en: http://www.bibliotecavirtualdeandalucia.es/catalogo/consulta/registro.cmd?id $=6353$.

Martínez Medina, África. «El palacio del duque del Infantado en las Vistillas. Su definitiva configuración en el siglo XVIII". En Anales del Instituto de Estudios Madrileños, tomo XXVIII. Madrid: Consejo Superior de Investigaciones Científicas, 1990, pp. 85-99.

MartíneZ Medina, África. Espacios privados de la mujer en el siglo XVIII. Madrid: Horas y Horas, 1995.

MARTínEZ MEDINA, África. «La vivienda aristocrática, escenario de la fiesta: festejos realizados por los Condes-Duques de Benavente con motivo de la exaltación al trono de Carlos IV, 19 de enero de 1789". En ROMERo FERrer, Alberto (coord.). De la Ilustración al romanticismo 1750-1850: VI encuentro "Juego, fiesta y transgresión" (Cádiz 16, 17 y 18 de octubre de 1991). Editorial Árbol académico, 1995, pp. 309-317.

Martínez Medina, África. Palacios madrileños del siglo XVIII. Madrid: La Librería, 1997.

MuÑOZ Roca-TALLADA, Carme. La condesa-duquesa de Benavente: una vida en unas cartas. Madrid: Espasa-Calpe, 1955.

Navascués Palacio, Pedro. "Antonio López Aguado, Arquitecto Mayor de Madrid (17641831)». Villa de Madrid, 1971, n. ${ }^{\circ} 33$, pp. 84-89.

NavascuÉs Palacio, Pedro. «La Alameda de Osuna: una villa suburbana». Revista Estudios Pro-Arte, 1975, n. ${ }^{\circ}$ 2, pp. 6-26.

Navascués Palacio, Pedro. Palacios madrileños del siglo XVIII. Madrid: Ayuntamiento de Madrid, 1978.

Navascués Palacio, Pedro. "Casas-palacio de la familia Osuna». En Jardines clásicos madrileños. Madrid: Museo Municipal, 1981, pp. 125-133.

PÉrez Hernández, María Isabel. «El jardín histórico El Capricho de la Alameda de Osuna». En Madrid Histórico. Madrid: Editorial La Librería, 2014, pp. 41-45.

Pérez Hernández, María Isabel. "El Ramal de El Capricho en la Alameda de Osuna. La presencia francesa en el jardín durante la Guerra de la Independencia». Anales del Instituto de Estudios Madrileños, tomo LIV. Madrid: Consejo Superior de Investigaciones Científicas, 2015, pp. 151-182.

PÉREZ Hernández, María Isabel. "Los palacios urbanos y las villas suburbanas de la casa nobiliaria de Osuna en la conformación de las periferias oeste y este de Madrid». En 
LA IX DUQUESA DE OSUNA Y EL JARDÍN DE EL CAPRICHO (MADRID): LA RECEPCIÓN DE LA ANTIGÜEDAD...

Alberto Alves, Luis y García García, Francisco (coords.). V Congresso Internacional Cidades Criativas: Libro de Actas, vol. 1, 2017, pp. 19-44.

REMón MEnÉndez, Juan. «The Alameda of The Duchess of Osuna: A Garden of Ideas». Journal of Garden History, 1993, vol. 13, pp. 224-240.

RODríGuez ROMERO, Eva. "El jardín paisajista y la mujer en España: la Alameda de Osuna, el Casino de la Reina y Vista Alegre». En La mujer en el arte español. Actas de las VIII Jornadas de Arte (Departamento de Historia del Arte Diego Velázquez). Madrid: Centro de Estudios Históricos, CSIC, 1996, pp. 347-366.

Sánchez-Fayos Calbuig, Teresa. Los jardines del Madrid moderno. Madrid: Departamento de Estudios y Comunicación, Gerencia Municipal de Urbanismo, 2001.

SCHrÖDER, Stephan. «Las series de los Doce Emperadores». En AA. VV. El coleccionismo de escultura clásica en España. Madrid: Museo del Prado, 2001, pp. 43-60.

Sото CABA, María Victoria. "El jardín romántico en la España ilustrada: una visión en la literatura». Espacio, Tiempo y Forma, 1993, Serie VII, H. ${ }^{a}$ del Arte, tomo 6, pp. 407-432.

Soto CaBA, María Victoria. "Jardines de la Ilustración y el Romanticismo en España». En ButTlar, Adrian von. Jardines del Clasicismo y el Romanticismo. El jardín paisajista. Madrid: Editorial Nerea, 1993, pp. 279-283.

Summerson, John. The Classical Language of Architecture. Londres: Thames and Hudson, 1980 (edición revisada y ampliada. Original publicado en 1963).

TOVAR MarTín, Virginia. El real sitio de Aranjuez y el Arte cortesano del siglo XVIII. Catálogo de exposición. Madrid: Patrimonio Nacional, D.L., 1987.

TOVAR MARTín, Virginia. Relaciones artísticas entre Madrid y París en el siglo XVIII. Madrid: Artes Gráficas Municipales, 1990.

WatKIn, David. «La arquitectura». En JENKYNS, R. (ed.). El legado de Roma. Una nueva valoración. Barcelona: Editorial Crítica, 1995, pp. 298-328. 